\title{
KESEPIAN PADA LANJUT USIA
}

\author{
Nor Mita Ika Saputri \\ Khairul Amri \\ Program Studi Bimbingan dan Konseling \\ Email : normita.ika@um-tapsel.ac.id ; khairul.amri@um-tapsel.ac.id
}

\begin{abstract}
Abstrak
Penelitian ini bertujuan untuk melihat gambaran kesepian yang dialami para lanjut usia di panti werdha Subulussalam Kabupaten Padang Lawas. Peneliti menggunakan metode kualitatif karena peneliti ingin melakukan penelitian terhadap suatu fenomena dalam konteks alamiah (apa adanya), serta untuk memperoleh pemahaman jelas tentang realitas dan kondisi yang nyata kehidupan responden dalam penelitian ini. Dalam penelitian ini, terdapat dua orang responden yaitu AS usia 75 tahun, dan LM 68 tahu. Teknik sampling yang digunakan dalam penelitian ini adalah purposive sampling. Pada penelitian ini peneliti hanya menggunakan metode observasi dan wawancara. Observasi terhadap responden, sedangkan wawancara kepada responden dan informan penelitian, yaitu seorang pegasuh di panti werdha. Metode analisis yang digunakan adalah analisis tematik.

Berdasarkan hasil penelitian dapat disimpulkan bahwa kesepian dari kedua narasumber primer relatif besar. Kesepian pada subjek sebenarnya sudah dirasakan oleh keduanya sebelum masuk panti werdha, dengan adanya hambatan dari perkembangan lanjut usia serta kurang sesuainya lingkungan disekitar panti dengan harapan kedua subjek yang masih membutuhkan perhatian dan kasih sayang dari keluarga masing-masing menambah rasa kesepian yang dialami oleh kedua subjek menjadi semakin besar. Adanya perbedaan pengungkapan perasaan kesepian pada lansia laki-laki dengan lansia perempuan. Lansia laki-laki yang mengalami kesepian masih dapat mengontrol ekspresi emosionalnya akan perasaan kesepian sehingga ketika merasakan hal tersebut lansia laki-laki tidak dapat terlihat dengan jelas bahwa subjek benar-benar sedang mengalaminya, sebaliknya lansia perempuan cenderung mudah mengutarakan ekspresi emosional ketika mengalami kesepian.
\end{abstract}

Kata kunci : Kesepian, Lansia

\section{PENDAHULUAN}

Manusia dalam perkembangannya akan mengalami serangkaian periode yang berurutan, mulai dari periode prenatal hingga lanjut usia. Semua individu mengikuti pola perkembangan dengan pasti dan dapat diramalkan. Setiap masa yang dilalui merupakan tahap-tahap yang saling berkaitan dan tidak dapat diulang kembali. Hal-hal yang terjadi di awal perkembangan individu akan memberikan pengaruh terhadap tahaptahap selanjutnya. Salah satu tahap yang akan dilalui oleh individu tersebut adalah masa lanjut usia atau lansia.
Lanjut usia dapat mengalami perubahan fisik, mental dan emosional seiring dengan bertambahnya usia mereka. Tetapi dengan adanya bantuan dan dukungan dari keluarga, teman-teman, dan pemberi pelayanan perawatan kesehatan, maka sebagian besar masalah mental dan emosional yang berat dapat dicegah. Agar lanjut usia dapat menikmati kehidupan di hari tua sehingga dapat bergembira atau merasa bahagia, diperlukan dukungan dari orang-orang yang dekat dengan mereka. Dukungan tersebut 
bertujuan agar lansia tetap dapat menjalankan berusia antara 65-80 tahun dan tinggal di kegiatan sehari-hari secara teratur dan tidak panti werdha Subulussalam Sibuhuan berlebihan.

Berdasarkan pengamatan dan wawancara Kabupaten Padang Lawas.

Teknik sampling yang digunakan dalam awal, dapat terlihat para lansia merasa penelitian ini adalah purposive sampling, kesepian karena kurang diperhatikan yaitu pemilihan subyek berdasarkan sifat dan keluarga. Perasaan kesepian tersebut semakin ciri tertentu yang dianggap mempunyai bertambah ketika fisik mereka menurun, sangkut paut yang erat dengan ciri-ciri atau karena lansia tidak dapat melakukan terlalu sifat populasi yang sudah diketahui banyak aktivitas untuk mengurangi atau sebelumnya.

menghilangkan perasaan kesepian yang dialami.

Dengan mengetahui kondisi-kondisi itu, maka keluarga, pemerintah, masyarakat atau lembaga sosial lainnya dapat memberikan perlakuan sesuai dengan masalah yang menyebabkan orang lanjut usia tergantung pada orang lain. Jika lanjut usia dapat mengatasi persoalan hidupnya maka mereka dapat ikut serta mengisi pembangunan salah satunya yaitu tidak tergantung pada orang lain. Dengan demikian angka ratio ketergantungan akan menurun, sehingga beban pemerintah akan berkurang.

Berdasarkan permasalahan yang dialami oleh lanjut usia maka peneliti tertarik untuk meneliti gambaran Kesepian Pada Lanjut Usia di Panti Werda Subulussalam.

\section{Metode Penelitian}

Penelitian kualitatif menghasilkan dan mengolah data yang sifatnya deskriptif, seperti transkrip wawancara, cacatan lapangan, gambar, rekaman video, foto, dan lain sebagainya. Peneliti menggunakan metode kualitatif karena peneliti ingin melakukan penelitian terhadap suatu fenomena dalam situasi dimana fenomena tersebut dapat dilihat dalam konteks alamiah (apa adanya), serta peneliti dapat memperoleh pemahaman jelas tentang realitas dan kondisi yang nyata kehidupan responden dalam penelitian ini. Atas beberapa pertimbangan peneliti, seperti jumlah responden yang terbatas dan untuk menggali lebih dalam maka pada penelitian ini peneliti akan menggunakan salah satu jenis pendekatan kualitatif yaitu studi kasus.

Dalam penelitian ini, akan menggunakan dua orang responden yaitu usia lanjut yang
Pada penelitian ini peneliti hanya menggunakan metode observasi dan wawancara.

Metode analisis yang digunakan adalah analisis tematik, yaitu proses mengkode informasi yang dapat menghasilkan daftar tema, model tema atau indikator yang kompleks, kualifikasi yang biasanya terkait dengan tema itu, atau hal-hal diantara gabungan yang telah disebutkan.

\section{Hasil Penelitian Dan Pembahasan}

Penelitian ini dilakukan di Panti Subulussalam Kecamatan Barumun Kabupaten Padang Lawas. Penelitian dilakukan pada bulan Pebruari sampai April 2017. Responden berjumlah dua orang dengan karakteristik: 1) usia 65-80 tahun; 2) dan tinggal di panti werdha Subulussalam. Data responden penelitian disajikan pada tabel 4.1 berikut:

\section{Tabel 1}

Responden penelitian

\begin{tabular}{|c|c|c|c|c|}
\hline No & Nama/inisial & $\begin{array}{c}\text { Jenis } \\
\text { kelamin }\end{array}$ & Usia & Status \\
\hline 1 & AS & P & 75 & Janda \\
\hline 2 & LM & L & 68 & Duda \\
\hline
\end{tabular}

Pelaksanaan penelitian ini dimulai pada tanggal 13 Februari 2017. Sebelum melakukan penelitian, peneliti terlebih dahulu mempersiapkan hal-hal yang dibutuhkan dalam penelitian. Mulai dari tempat penelitian sampai dengan perjanjian penelitian. Peneliti membuat jadwal untuk melakukan wawancara dengan responden dan informan penelitian. 


\section{Hasil penelitian dan Pembahasan Gambaran kesepian responden 1}

AS memiliki dua orang anak namun, AS tidak mengetahui keberadaan anakanaknya. Rumah AS juga sudah dijual. sedih dan kecewa dengan keadaan saat ini. AS merasakan kehilangan, yaitu dengan ditinggalkan oleh keluarganya yang selama ini menjadi motivasi hidupnya. Rasa kehilangan yang besar membuat AS menjadi kesepian yang sangat mendalam bagi dirinya, perasaan ditinggalkan, terlantar dan tidak ada yang memperhatikan serta memahami keadaan beliau membuat dampak kesehatan psikologis AS menjadi menurun dan menyebabkan rasa kesepian yang mendalam bagi beliau.

Beliau mengalami kesepian yang sangat mendalam lantaran ditinggalkan anakanak dan keluarganya dan sekarang hidup di Panti Subulussalam yang tempat tersebut memang mempunyai fungsi untuk menampung para lansia yang hidupnya kurang bahagia dan sejahtera.

Dengan lingkungan yang awalnya asing bagi AS, menambah rasa kesepiannya meningkat. Tinggal bersama penghuni Panti lainnya yang begitu banyak di tempat tersebut, membuat AS seharusnya mendapatkan hidup baru yang yang menyenangkan dengan situasi bersosialisasi lebih banyak orang lagi di tempat tersebut. Akan tetapi para penghuni satu dengan lainnya tidak memiliki cukup kedetakan secara emosional, dengan hanya mengetahui keadaan diluar secara umum dari masingmasing penghuni Panti tersebut tanpa adanya hubungan pertemanan yang erat. Sehingga AS masih saja merasakan kesepian karena tidak ada orang yang begitu dekat dengan beliau untuk berbagi semua yang dimilikinya.

Beliau yang mempunyai kemandirian di dalam dirinya membuat dirinya dapat menyesuaikan lingkunganya dengan baik, hal ini ditunjukkannya

ketika pertama kali masuk kedalam Panti Subulussalam yang hingga sampai saat ini tetapi pada kenyatannya setelah kejadian ibu mantap tinggal ditempat tersebut. AS yang pendiam dan sering menyendiri membuat dirinya kurang mendapatkan perhatian dan teman yang ada di dalam lingkungan Panti tersebut, hal ini terlihat ketika beliau hanya menjelaskan keseluruhan penghuni Panti tanpa ada satu pun nama penghuni yang terlihat menjadi teman dekat.

AS dapat mengatur semua kegiatannya dengan sendiri didalam kehidupan seharihari, meskipun ada beberapa kegiatan yang dilakukan oleh AS dalam bentuk bersamasama dengan lansia lain yang juga tinggal di Panti, akan tetapi keterbatasan fisik dan keinginan melakukan kegiatan yang berbedabeda banyak sekali yang melakukannya dengan keterbatasan masing-masing, sehingga AS melakukan pengaturan hidupnya dengan sendiri. Hal ini juga disebabkan karena sifat mandiri dari beliau yang sering melakukan kegiatannya sendiri, sehingga menyebabkan rasa kesepian yang dirasakan oleh AS tidak bisa hilang, lantaran hubungan sosial yang ada di lingkungan Panti kurang mendukung perkembangan lansia.

Jumlah pengasuh lansia dengan lansia penghuni Panti tersebut, menyebabkan kebutuhan perhatian yang harusnya diberikan oleh para lansia di tempat tersebut terpenuhi jadi berkurang. Salah satunya adalah AS, beliau kurang mendapatkan perhatian akan perawatan kesehatan dari pengasuh lansia karena beliau masih dianggap sanggup melaklukan semua kegiatannya dengan tenaganya dan juga menjaga kesehantannya sendiri.

Sikap terhadap perubahan lansia yang dialami oleh AS yaitu yang sudah menjadi lansia ini beliau ingin hidup bahagia bersama keluarganya, dengan hidup bersama keluarga yang dicintainya akan menambah semangat hidup LA dalam menjalani kesehariannya. Beliau dengan keadaanya sekarang yang sudah renta terhadap berbagai macam hal di lingkungannya memimpikan kehidupan yang bahagia dengan menimang cucu yang dibesarkan bersama oleh keluarganya, akan tetapi pada kenyatannya setelah kejadian ibu (1) 
AS meninggal dunia, keluarga yang mengalami penurunan dari berbagai aspek dicintainya meninggalkan AS seorang diri.

\section{Gambaran Kesepian Responden 2}

Ketika pertama kali LM masuk ke panti tersebut, beliau merasa biasa saja dengan kepindahannya dari rumah menuju Panti Werdha Subulussalam. Keadaan rumah yang sekarang dianggap beliau sebagai tempat bekerja, apabila beliau sudah merasakan asing dan merasa kesepian, Panti capek dan lemes biasanya kegiatan yang Subulussalam menjadi tujuan LM untuk dilakukan akan dihentikan sejenak untuk mendapatkan apa yang tidak dapat mengistirahatkan badannya yang sudah tidak didapatkan di rumahnya dulu, walaupun hati sanggup melakukan kegiatan lagi. Hal kecil beliau lebih merasakan nyaman hidup tersebut akan mengganggu aktivitas bersama keluarganya dari pada hidup di Panti keseharian dan mengurangi porsi hubunga Subulussalam, hal ini semakin memperjelas sosialisasi dengan lingkungan sekitar rasa kesepian yang dialam oleh LM sangat terutama LM yang mengalami kesepian mendalam meskipun beliau terlihat biasa saja tersebut, sehingga untuk mengembangkan di depan orang lain. Banyak aspek sosial pada lingkungan dan lansia yang tinggal bersama beliau ditempat mengurangi rasa kesepian yang dialami oleh tersebut, akan tetapi LM masih belum bisa LM menjadi terganggu karena hambatan berhubungan akrab dengan lansia lainnya tersebut. Kondisi tersebut dapat karena hanya kegiatan tertentu saja mereka mempengaruhi dampak psikologis bagi LM berkumpul dan melakukan kegiatan bersama, dan lansia lainnya, merasakan tidak mampu selain kegiatan tersebut biasanya LM dan lagi melakukan semua kegiatan yang lansia lainnya sibuk dengan kegiatan masing- memberikan perkembangan dari masing. Keadaan yang dialami oleh LM berbagai aspek perkembangan lansia, seperti tersebut membuatnya terasa acuh dengan perkembangan kognitif, psikomotorik dan lingkungan di sekitar, seharusnya dengan sosial yang dimiliki lansia memberikan lingkungan dan teman sebaya yang dampak yang kurang bagus bagi beliau dan mempunyai

tujuan sama yaitu tinggal di Panti Subulussalam akan lebih memudahkan para lansia tersebut untuk saling berhubungan antara satu dengan lainnya, saling berbagi cerita, pengalaman serta kehidupan yang sudah beranjak senja. Hal ini masih menjauhkan LM dari rasa kebersamaan dan bahagia yang dicari ditempat tersebut, beliau masih merasakan kesepian yang disebabkan oleh keluarganya dengan kurang yar memperhatikan, menyayangi dan berbagi bersama seperti layaknya kehidupan berkeluarga yang diinginkan oleh LM.

Kondisi fisik dari LM cukup baik, lansia butuh perhatian ekstra karena adanya seperti yang dialami lansia umunya. Kondisi perubahan dari segi kognitif, fisik bagi lansia seperti beliau pada psikomotorik dan afektif yang menurun umumnya sering merasakan capekcapek dibandingkan para lansia yang dulunya masih disemua tubuh dan, karena tubuh lansia yang muda, salah satunya yang menagalami hal 
Volume 3 Nomor 1, Halaman 1-81, Januari--Juni 2018

RISTEKDIK | Jurnal Bimbingan dan Konseling

P-ISSN: 2527-4244, E-ISSN : 2541-206X

tersebut adalah LM, beliau rumah keluarga LM yang kurang menerima kurang mendapatkan perhatian dari pengasuh keberadaan beliau, keluarga yang dicintainya lansia karena beliau dianggap pengasuh meninggalkan LM dengan tidak lansia sanggup melakukan semua mempercayai dan menganggap beliau kegiatannya dengan tenaganya dan juga sebagai beban hidup bagi keluarganya yang dapat menjaga kesehatannya sendiri. selalu dicintainya sepenuh hati. Rasa

Keluarga yang seharusnya menjadi kesepian yang yang disebabkan oleh hal penopang dan semgangat hidup bagi LM tersebutlah yang mendorong LM untuk tetap yang sudah menjadi lansia, tidak tinggal di Panti Werdha yang menjadi tujuan memberikan apa yang dibutuhkan beliau akhirnya sekarang, walaupun ada harapan untuk merasakan dan menikmati hari-harinya yang diinginkan oleh LM yaitu kembali yang sudah menuju akhir dari kehidupan. LM tinggal bersama-sama dengan yang tinggal di Panti Subulussalam, keluarganya yang menjadi satu-satunya mendapatkan perawatan dari pengasuh lansia harapan dan motivasi hidup yang sangat kuat di tempat tersebut, masih berkeinginan bagi beliau. Tingal bersama lansia lainnya bahwa yang memperhatikan kesehatan dan yang juga memiliki nasib dan tujuan yang segala macam lainnya adalah keluarganya hampir sama dengan LM untuk menetap di sendiri, beliau masih ingin mendapatkan Panti Subulussalam, masih belum bisa perhatian dan kasih sayang oleh anak dan menghilangkan rasa kesepian yang dialami keluarganya, meskipun dulunya lingkungan oleh beliau. Rasa kesepian akan kurangnya keluarga LM kurang menerima keberadaanya perhatian dan kasih sayang yang seharusnya yang sudah mengalami lansia. Beliau ingin diberikan oleh orang terdekat LM yaitu menghilangkan rasa kesepian yang keluarganya sendiri masih membayangi dialaminya dengan meminta perhatian dan beliau hingga sekarang, dengan lingkungan kasih sayang dari yang ada di Panti Subulussalam belum bisa keluarganya. Pihak panti yang mengurus mengurangi kesepian yang sangat mendalam semua kebutuhan LM sebenarnya sudah bagi LM.

memberikan perhatian dan kasih sayang yang selama ini kurang didapatkan KESIMPULAN

beliau pada keluarganya, tetapi tetap saja perhatian dan kasih sayang dari keluarga tidak mudah digantikan oleh siapa saja, disimpulkan bahwa kesepian dari kedua walaupun dengan berbagai cara yang akan narasumber primer relatif besar. Kesepian membuat LM tidak lagi merasakan kesepian pada subjek sebenarnya sudah dirasakan oleh oleh pihak panti. Perhatian dari orang yang keduanya sebelum masuk panti werdha, dekat bahkan terlebih keluarga akan dengan adanya hambatan menjadikan LM dapat menghilangkan rasa dari perkembangan lanjut usia serta kurang kesepiannnya.

Sikap terhadap perubahan lansia yang sesuainya lingkungan di sekitar panti dengan dialami on subek yang masih dialami oleh beliau yaitu ingin hidup bahagia membutuhkan perhatian dan kasih sayang bersama keluarganya, dengan hidup bersama dari keluarga masing-masing menambah rasa keluarganya akan menambah semangat hidup kesepian yang dialami oleh LM dalam menjalani kesehariannya, dengan kedua subjek menjadi semakin besar. Adanya keadaanya sekarang yang sudah mencapai perbedaan pengungkapan perasaan kesepian akhir hidupnya memimpikan kehidupan yang pada lansia laki-laki dengan lansia bahagia dengan menimang cucu yang perempuan. Lansia laki-laki yang mengalami dibesarkan bersama oleh kesepian masih dapat mengontrol ekspresi kanak-anaknya, akan tetapi pada emosionalnya akan perasaan kesepian kenyatannya setelah kejadian yang ada di sehingga ketika merasakan hal tersebut lansia 
Volume 3 Nomor 1, Halaman 1-81, Januari--Juni 2018

RISTEKDIK | Jurnal Bimbingan dan Konseling

P-ISSN: 2527-4244, E-ISSN : 2541-206X

laki-laki

tidak

dapat terlihat dengan jelas bahwa subjek

benar-benar sedang mengalaminya,

sebaliknya lansia perempuan cenderung

mudah mengutarakan ekspresi emosional

ketika mengalami kesepian.

\section{DAFTAR PUSTAKA}

Salamah. 2005. Kondisi Psikis Dan Alternatif Penanganan Masalah Kesejahteraan Sosial Lansia Di Panti Werda. Jurnal PKS (11) 55-61.

Sanjaya, Wina. 2011. Penelitian Tindakan Kelas. Jakarta: Kencana Prenada Media Grup.

Santrock, J.W. 2003. Perkembangan Dewasa dan Lansia. Jakarta: Erlangga. 